Dept. of Food Hygiene,

Faculty of Veterinary Medicine, Cairo University

\title{
FATE OF SALMONELLA ENTERICA SEROVAR ENTERITIDIS DURING MANUFACTURE AND STORAGE OF HOME MADE MAYONNAISE
}

(With 6 Tables)

By

\section{NEVEEN S. M. SOLIMAN and SALWA A. ALY}

(Received at 13/12/2008)

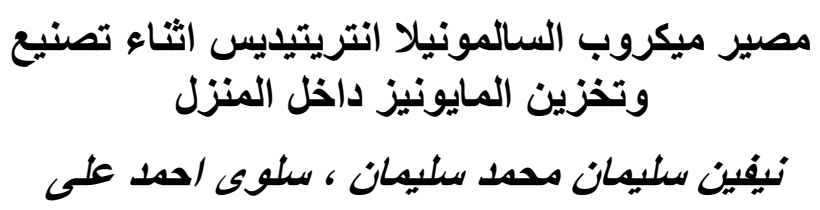

يهدف البحث الى تصنيع المايونيز داخل المنزل وذلك بتحضير ستة وصفات مختلفة من لئل

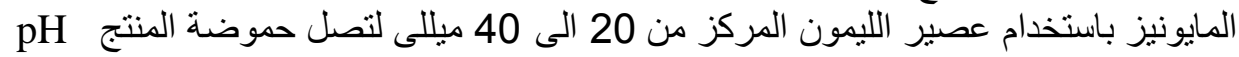

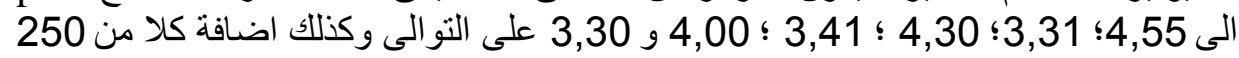

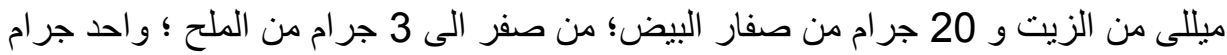

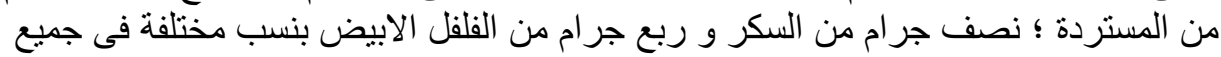

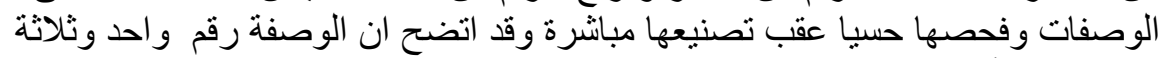

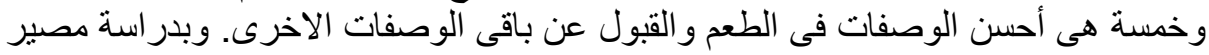

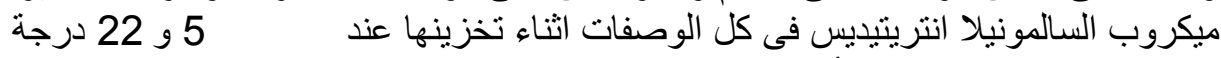

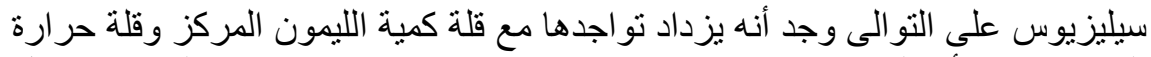

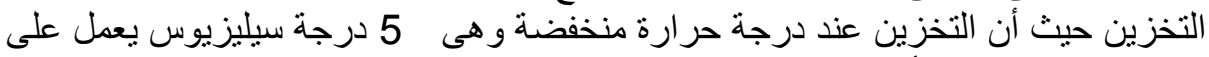

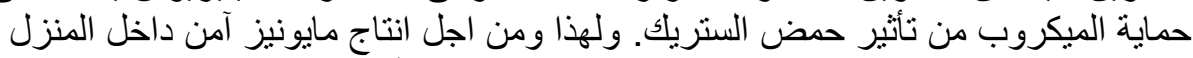

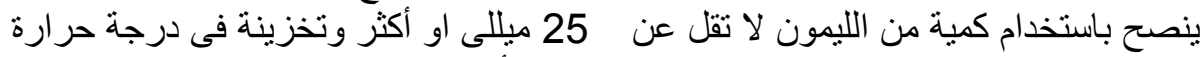

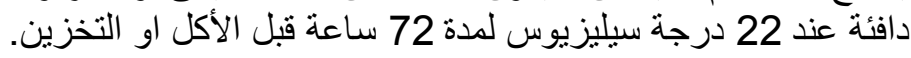

\section{SUMMARY}

In this study, six different recipes of home made mayonnaise were prepared using lemon juice in order to bring down $\mathrm{pH}$ to $4.55 \pm 0.01 ; 3.31 \pm 0.10 ; 4.30 \pm 0.06 ; 3.41 \pm 0.04 ; 4.0 \pm 0.11$ and $3.30 \pm 0.03$, respectively. The content of oil $(250 \mathrm{ml})$, egg yolk $(20 \mathrm{~g})$, citric acid (> 5 $\% \mathrm{w} / \mathrm{v})(20-40 \mathrm{ml})$, salt $(0-3 \mathrm{~g})$, mustard $(1 \mathrm{~g})$, sugar $(0.5 \mathrm{~g})$ and white pepper $(0.25 \mathrm{~g})$ varied among the different recipes. All recipes were scored for their sensory evaluation. The results showed that Recipe 1; 3 and 5 gained higher grades and higher acceptability for most sensory attributes than the other recipes. The behavior of Salmonella enterica serovar Enteritidis in home made mayonnaise was studied at two 
holding temperatures $\left(5\right.$ and $\left.22^{\circ} \mathrm{C}\right)$. The presence value increased whereas the amount of citric acid and storage temperature decreased. Storage of mayonnaise at low temperature $\left(5^{\circ} \mathrm{C}\right)$ protected the Salmonella enteritidis against the effect of citric acid. The fate of Salmonella enteritidis appeared to be largely dependent on the temperature of the storage. Therefore, for production of safe home made mayonnaise, the use of citric acid at $25 \mathrm{ml}$ or more and storage in warm place at $22^{\circ} \mathrm{C}$ for 72 hours before consumption or refrigeration was recommended.

Key words: Home made mayonnaise, Salmonella enteritidis, sensory analysis, holding temperature.

\section{INTRODUCTION}

Mayonnaise is a widely consumed product, forming the foundation of one half of all salad dressings and the basis of many other products such as tartar sauce and coleslaw (Hoffmann, 1989; Radford and Board, 1993). It is a kind of semi solid oil in water emulsion, traditionally prepared by carefully mixing a mixture of egg yolk, and oil to maintain closely packed foam of oil droplets. It may also include salts, mustard, sweeteners and other optional ingredients. The emulsion is formed by slowly blending oil with a premix consists of egg yolk, citric acid and or vinegar as well as mustard because mixing the oil and aqueous phase at once result in formation of water in oil emulsion (Anon, 1989; McClements, 1999; Smittle, 2000; Liu et al., 2007 and Kim et al., 2009).

Mayonnaise was first produced commercially in the early 1900's, and became popular in America from 1917 to 1927 (Anon, 2000 and Grodzka et al., 2005) and recently in Japan, where sales increased by $21 \%$ a year from 1987 to 1990 (Brabant, 1992). A wide range of commercial mayonnaise is available, but many individuals and caterers still prefer to use home made mayonnaise due to its lowered tartness and better texture (Depree and Savage, 2001 and Rodrigue et al., 2008). However, the home made mayonnaise has been identified as one of the causes of Salmonella food poisoning. Most of the outbreaks of food poisoning are transmitted through the home made mayonnaise which made from fresh eggs with Salmonella enteritidis (Murchie et al., 2008). This situation might be due to several factors such as the habit of preparing mayonnaise frequently in home or in restaurants and a relatively high percentages of eggs being contaminated with Salmonella enteritidis (Pearales and Audicana, 1989; Whiting and Buchanan, 1997; 
Stadelman, 1999; Davis and Reeves, 2002; Morgan et al., 2007 and Irwin et al., 2008).

Salmonella enteritidis is a food borne pathogen that causes food borne illness. Symptoms of this illness mainly consist of nausea, vomiting, abdominal pain, headache, chills and diarrhea (Knabel, 1995 and Holtby et al., 2006). The fate of Salmonella enteritidis in home made mayonnaise is determined in part by the type and concentration of the acidulant, as well as, the time and temperature of storage (Pearales and Garcia, 1990; Radford, 1994 and Ordonez et al., 2009). Considering the possible contamination and proliferation of pathogenic Salmonella enterica serovar Enteritidis during processing and storage of home made mayonnaise which may lead to public health hazard, this study was conducted to determine the conditions in which Salmonella enteritidis could be destroyed depending on the concentration of the acid used, as well as, the time and temperature of storage.

\section{MATERIALS and METHODS}

\section{Eggs:}

Specific pathogen free (S.P.F.) eggs were obtained from Nile S.P.F. project, Agriculture research center (Kom- Oshim- Fayoum governerate).

\section{Culture:}

Salmonella enterica serovar enteritidis strain was obtained from the culture collection of Health ministry central laboratories on a slope of nutrient agar and then was maintained on XLD agar (Oxoid) at $37^{\circ} \mathrm{C}$ for 48 hours.

\section{Mayonnaise preparation:}

The experiment is based on input materials provided by six types of mayonnaise recipes according to Xiong et al. (1999).

Table 1: The experimental design table.

\begin{tabular}{|l|l|l|l|l|l|l|}
\hline Ingredients & Recipe 1 & Recipe 2 & Recipe3 & Recipe 4 & Recipe 5 & Recipe 6 \\
\hline $\begin{array}{l}\text { Sunflower } \\
\text { oil/ml }\end{array}$ & 250 & 250 & 250 & 250 & 250 & 250 \\
\hline Egg yolk/g & 20 & 20 & 20 & 20 & 20 & 20 \\
\hline $\begin{array}{l}\text { Citric acid/ml } \\
(>5 \% \mathrm{w} / \mathrm{v})\end{array}$ & 20 & 40 & 25 & 40 & 30 & 40 \\
\hline Salt/g & 3 & 0 & 1.5 & 1.5 & 0 & 3 \\
\hline Mustard/g & 1 & 1 & 1 & 1 & 1 & 1 \\
\hline $\begin{array}{l}\text { White } \\
\text { pepper/g }\end{array}$ & 0.25 & 0.25 & 0.25 & 0.25 & 0.25 & 0.25 \\
\hline Sugar/g & 0.5 & 0.5 & 0.5 & 0.5 & 0.5 & 0.5 \\
\hline
\end{tabular}


The mayonnaise was prepared using the following recipe: $20 \mathrm{~g}$ egg yolk, $250 \mathrm{ml}$ pure sunflower oil, $1 \mathrm{~g}$ mustard, $0.5 \mathrm{~g}$ sugar, $0.25 \mathrm{~g}$ white pepper and different amounts of the citric acid solution (20 to 40 $\mathrm{ml}$ ), and salt (0-3 g). Lower content of citric acid and egg yolk could not produce mayonnaise. Mayonnaise was prepared as follows: (I) all ingredients except the oil were mixed with an electronic mixer and (ii) oil was poured steadily while blending at high speed. After preparation, $\mathrm{pH}$ values were measured at room temperature for all mayonnaise samples, using a $\mathrm{pH}$ meter (Orion, digital, $\mathrm{pH}$ ). Fresh mayonnaise samples were analyzed for sensory qualities. The experiment was conducted in three repetitions.

\section{Sensory analysis:}

For the purpose of evaluating sensory qualities, a commission composed of three qualified and experienced tasters trained in the field of emulsions was appointed, while sensory attributes of coded mayonnaise samples were tasted in a standard sensory laboratory (in order to guarantee objectivity as far as the sample brand names are concerned). The samples were evaluated by the same sensory commission. Strict confidentiality rules were observed during testing. All testing posts in the sensory laboratory had identical conditions. The room temperature was approximately $20{ }^{\circ} \mathrm{C}$. Lighting of the room was also the same throughout the experiment. The commission was given representative mayonnaise samples of 5 grams placed on white china plates. The sensory commission assessed the samples separately one by one in groups composed of 6 samples. The break between the groups to be tasted was one hour. The test had three rounds, meaning that each mayonnaise sample had been prepared by following the same recipe in three batches. The analysis was performed by scoring sensory attributes by assigning a non-structured scale from 1 to 10 points, where higher score means more expressed attribute according to Abu-Salem and Abou-Arab (2008).

\section{Inoculation and incubation of Mayonnaise:}

A loopful of cultutre strain of Salmonella enterica serovar enteritidis from a XLD agar at $4^{\circ} \mathrm{C}$ was inoculated into $10 \mathrm{ml} 0 \cdot 1 \%$ peptone water (Oxoid) containing $10 \%$ egg yolk emulsion (Oxoid). The culture was incubated at $37^{\circ} \mathrm{C}$ for 24 hours (h). The culture was then added to the mayonnaise at the rate of $1 \mathrm{ml}$ per $100 \mathrm{~g}$ to give approximately $10^{6} \mathrm{cfu} / \mathrm{g}$ and blended with stomacher for $2 \mathrm{~min}$. No separation of mayonnaise was observed due to blending. The inoculated mayonnaise samples were immediately transferred into sterile containers 
and stored at $5^{\circ} \mathrm{C}$ and $22^{\circ} \mathrm{C}$ for 9 days according to Marshall (1992) and Roberts et al. (1995).

\section{Microbiological analysis:}

The samples were taken at time intervals after contamination for viable counts. At each time interval, $10 \mathrm{~g}$ contaminated mayonnaise were weighed into a stomacher bag, $90 \mathrm{ml}$ Buffered Peptone Water (BPW) (Oxoid) added and the mixture homogenized for 1 min with stomacher. Serial ten fold dilutions in $0.1 \%$ peptone diluents were plated onto XLD agar (Oxoid) using the surface spread method. The XLD agar plates were incubated at $37^{\circ} \mathrm{C}$ for at least 24 hours and the viable colonies then enumerated. For presence/absence tests, a $25 \mathrm{~g}$ mayonnaise sample was added to $225 \mathrm{ml} 1 \%$ Buffer peptone water in a sterile container at each time interval. The mixture was swirled well and incubated at $37^{\circ} \mathrm{C}$ for 24 hours. After incubation, $0 \cdot 1 \mathrm{ml}$ of the mixture or enrichment was added to $4 \mathrm{ml}$ Rappaport-Vassiliadis broth (Difco) and incubated at $42^{\circ} \mathrm{C}$ for $18 \mathrm{~h}$. Loopfull from the secondary enrichment was streaked on XLD agar media and incubated at $37 \mathrm{C}^{\circ}$ for at least 24 hours according to Jay (1992) and Donaghy and Madden (1993). All experiments in this study were performed in triplicate.

\section{RESULTS}

Table 2: Sensory evaluation and $\mathrm{pH}$ values of home made mayonnaise recipes during processing at zero time.

\begin{tabular}{|l|l|l|l|l|l|l|}
\hline $\begin{array}{l}\text { Sensory } \\
\text { evaluation } \\
\text { and pH } \\
\text { values }\end{array}$ & \multicolumn{4}{|l|}{ Recipes } \\
\cline { 2 - 7 } & 1 & 2 & 3 & 4 & 5 & 6 \\
\hline Taste & $9 \pm 0.01$ & $5 \pm 0.01$ & $9 \pm 0.06$ & $6 \pm 0.01$ & $9 \pm 0.03$ & $8 \pm 0.06$ \\
\hline Flavor & $9 \pm 0.01$ & $6 \pm 0.03$ & $9 \pm 0.03$ & $7.5 \pm 0.06$ & $9 \pm 0.03$ & $8 \pm 0.01$ \\
\hline Color & $9.5 \pm 0.03$ & $9 \pm 0.06$ & $9 \pm 0.01$ & $9.5 \pm 0.01$ & $9.5 \pm 0.01$ & $9 \pm 0.03$ \\
\hline Appearance & $9 \pm 0.01$ & $9.5 \pm 0.03$ & $9.5 \pm 0.06$ & $9 \pm 0.03$ & $9.5 \pm 0.05$ & $9.5 \pm 0.03$ \\
\hline $\begin{array}{l}\text { Overall } \\
\text { acceptability }\end{array}$ & $9.1 \pm 0.01$ & $7.3 \pm 0.03$ & $9.1 \pm 0.05$ & $8 \pm 0.01$ & $9.2 \pm 0.03$ & $8.6 \pm 0.01$ \\
\hline pH & $4.55 \pm 0.01$ & $3.31 \pm 0.10$ & $4.30 \pm 0.06$ & $3.41 \pm 0.04$ & $4.0 \pm 0.11$ & $3.30 \pm 0.03$ \\
\hline
\end{tabular}

$*_{ \pm}$Standard Error, S.E. 
Table 3: Growth of Salmonella enteritidis in home made mayonnaise recipes during storage at $5^{\circ} \mathrm{C}$.

\begin{tabular}{|c|c|c|c|c|c|c|}
\hline \multirow[t]{2}{*}{ Time } & \multicolumn{6}{|c|}{ Recipes (cfu/g) } \\
\hline & 1 & 2 & 3 & 4 & 5 & 6 \\
\hline 0 time & $6 \times 10^{5} \pm 0.04$ & $6 \times 10^{5} \pm 0.06$ & $6 \times 10^{5} \pm 0.05$ & $6 \times 10^{5} \pm 0.04$ & $6 \times 10^{5} \pm 0.03$ & $6 \times 10^{5} \pm 0.07$ \\
\hline $24 \mathrm{~h}$ & $58 \times 10^{4} \pm 0.03$ & $24 \times 10^{4} \pm 0.03$ & $54 \times 10^{4} \pm 0.02$ & $26 \times 10^{4} \pm 0.04$ & $58 \times 10^{4} \pm 0.12$ & $19 \times 10^{4} \pm 0.03$ \\
\hline $48 \mathrm{~h}$ & $48 \times 10^{4} \pm 0.12$ & $21 \times 10^{4} \pm 0.02$ & $42 \times 10^{4} \pm 0.11$ & $18 \times 10^{4} \pm 0.02$ & $56 \times 10^{4} \pm 0.06$ & $13 \times 10^{4} \pm 0.03$ \\
\hline $72 \mathrm{~h}$ & $69 \times 10^{3} \pm 0.06$ & $44 \times 10^{3} \pm 0.05$ & $57 \times 10^{3} \pm 0.10$ & $36 \times 10^{3} \pm 0.01$ & $64 \times 10^{3} \pm 0.38$ & $31 \times 10^{3} \pm 0.06$ \\
\hline $96 \mathrm{~h}$ & $55 \times 10^{3} \pm 0.03$ & $16 \times 10^{3} \pm 0.04$ & $32 \times 10^{3} \pm 0.22$ & $23 \times 10^{3} \pm 0.22$ & $61 \times 10^{3} \pm 0.05$ & $17 \times 10^{3} \pm 0.23$ \\
\hline $120 \mathrm{~h}$ & $45 \times 10^{2} \pm 0.01$ & $6 \times 10^{2} \pm 0.01$ & $36 \times 10^{2} \pm 0.31$ & $18 \times 10^{2} \pm 0.04$ & $55 \times 10^{2} \pm 0.01$ & $10 \times 10^{2} \pm 0.06$ \\
\hline $144 \mathrm{~h}$ & $85 \times 10 \pm 0.01$ & $72 \times 10 \pm 0.02$ & $59 \times 10 \pm 0.16$ & $44 \times 10 \pm 0.11$ & $35 \times 10 \pm 0.50$ & $24 \times 10 \pm 0.11$ \\
\hline $168 \mathrm{~h}$ & $48 \times 10 \pm 0.02$ & $42 \times 10 \pm 0.11$ & $44 \times 10 \pm 0.01$ & $37 \times 10 \pm 0.05$ & $41 \times 10 \pm 0.03$ & $34 \times 10 \pm 0.05$ \\
\hline $192 \mathrm{~h}$ & $99 \pm 0.03$ & $35 \pm 0.01$ & $55 \pm 0.02$ & $34 \pm 0.01$ & $43 \pm 0.05$ & $30 \pm 0.01$ \\
\hline $216 \mathrm{~h}$ & ND & ND & ND & ND & ND & ND \\
\hline
\end{tabular}

* \pm Standard Errors, S.E. $\quad * *$ ND, not detected.

Table 4: Presence (+) /absence (-) of Salmonella enteritidis in home made mayonnaise recipes during storage at $5^{\circ} \mathrm{C}$.

\begin{tabular}{|c|c|c|c|c|c|c|c|c|}
\hline $\begin{array}{l}\text { Time } \\
\text { Recipes }\end{array}$ & $24 \mathrm{~h}$ & $48 \mathrm{~h}$ & $72 \mathrm{~h}$ & $96 \mathrm{~h}$ & $120 \mathrm{~h}$ & 144h & $168 \mathrm{~h}$ & $192 \mathrm{~h}$ \\
\hline 1 & + & + & + & + & + & + & + & + \\
\hline 2 & + & + & + & + & + & + & + & + \\
\hline 3 & + & + & + & + & + & + & + & + \\
\hline 4 & + & + & + & + & + & + & + & + \\
\hline 5 & + & + & + & + & + & + & + & + \\
\hline 6 & $\mathrm{D}$ & $\mathrm{D}$ & $\mathrm{d}$ & $\mathrm{d}$ & $\mathrm{D}$ & $\mathrm{d}$ & $\mathrm{d}$ & $\mathrm{D}$ \\
\hline
\end{tabular}

$\mathrm{d}^{*}=$ doubtful, one positive result from three experiments.

Table 5: Growth of Salmonella enteritidis in home made mayonnaise recipes during storage at $22^{\circ} \mathrm{C}$

\begin{tabular}{|c|c|c|c|c|c|c|}
\hline \multirow[t]{2}{*}{ Time } & \multicolumn{6}{|c|}{ Recipes (cfu/g) } \\
\hline & 1 & 2 & 3 & 4 & 5 & 6 \\
\hline 0 time & $6 \times 10^{5} \pm 0.09$ & $6 \times 10^{5} \pm 0.06$ & $6 \times 10^{5} \pm 0.11$ & $6 \times 10^{5} \pm 0.04$ & $6 \times 10^{5} \pm 0.08$ & $6 \times 10^{5} \pm 0.06$ \\
\hline $24 \mathrm{~h}$ & $11 \times 10^{3} \pm 0.11$ & $84 \pm 0.06$ & $30 \times 10^{3} \pm 0.08$ & $12 \times 10^{2} \pm 0.11$ & $32 \times 10^{3} \pm 0.07$ & $13 \times 10^{2} \pm 0.11$ \\
\hline $48 \mathrm{~h}$ & $55 \times 10^{2} \pm 0.06$ & ND & $75 \pm 0.05$ & ND & $89 \pm 0.01$ & ND \\
\hline $72 \mathrm{~h}$ & $300 \pm 0.01$ & ND & $\mathrm{ND}$ & ND & $\mathrm{ND}$ & ND \\
\hline $96 \mathrm{~h}$ & $84 \pm 0.03$ & ND & $\mathrm{ND}$ & ND & $\mathrm{ND}$ & ND \\
\hline $120 \mathrm{~h}$ & $62 \pm 0.02$ & ND & ND & ND & ND & ND \\
\hline $144 \mathrm{~h}$ & ND & ND & ND & ND & $\mathrm{ND}$ & ND \\
\hline $168 \mathrm{~h}$ & ND & ND & $\mathrm{ND}$ & ND & ND & ND \\
\hline $192 \mathrm{~h}$ & ND & ND & ND & ND & ND & ND \\
\hline $216 \mathrm{~h}$ & ND & ND & ND & ND & ND & ND \\
\hline
\end{tabular}

$* \pm$ Standard Errors, S.E. $\quad * *$ ND, not detected. 
Table 6: Presence (+)/ absence (-) of Salmonella enteritidis in home made mayonnaise recipes during storage at $22^{\circ} \mathrm{C}$.

\begin{tabular}{|l|l|l|l|l|l|l|l|l|}
\hline \multicolumn{1}{r|}{ Time } & $24 \mathrm{~h}$ & $48 \mathrm{~h}$ & $72 \mathrm{~h}$ & $96 \mathrm{~h}$ & $120 \mathrm{~h}$ & $144 \mathrm{~h}$ & $168 \mathrm{~h}$ & $192 \mathrm{~h}$ \\
\hline 1 & + & + & + & + & + & - & - & - \\
\hline 2 & + & d & - & - & - & - & - & - \\
\hline 3 & + & + & - & - & - & - & - & - \\
\hline 4 & + & d & - & - & - & - & - & - \\
\hline 5 & + & + & - & - & - & - & - & - \\
\hline 6 & + & d & - & - & - & - & - & - \\
\hline
\end{tabular}

$* \mathrm{~d}$, doubtful, one positive result from three experiments.

\section{DISCUSSION}

\section{Sensory analysis}

The sensory analyses were carried out on all recipes of mayonnaise samples include: color, taste, flavor, appearance, and overall acceptability were recorded in Table 2. The taste, flavor, color, appearance and over all acceptability showed higher scores in recipes 1 , 3 and 5 compared with the other recipes. These mayonnaise recipes samples contained balanced proportion of salt, citric acid and mustard that contributed to their taste. In recipes of relatively high content of citric acid, mayonnaise samples were characterized by a sour taste with $\mathrm{pH}$ value between 3.30-3.41 while recipes of low concentration of citric acid had $\mathrm{pH}$ values between 4.00-4.55. All recipes containing no salt were characterized by a flat and poor flavor. However, the color and appearance were not significantly affected in all recipes of mayonnaise, being in the range of 9-9.5. These results were in accordance with Meyer et al. (1995); Kishk (1997); Stefanow (1998); Xiong et al. (2000); Stern et al. (2001); Yang et al. (2001); Karas and Skvaraa (2002). Color is one of the most important quality attributes of mayonnaise which the consumer uses to select the mayonnaise brand from the grocer's shelf (Peressini et al., 1998; Depree and Savage, 2001 and Rujirat et al., 2007). The yellowish color is primarily provided by egg yolk carotenoids, while oil and mustard do not contribute a color simulating that provided by egg yolk (Abu-Jdayil, 2003 and Batista et al., 2006).

The fate of Salmonella enterica serovar enteritidis in mayonnaise recipes prepared with citric acid solution was recorded in Tables $3 \& 4$. 
The initial $\mathrm{pH}$ of home made mayonnaise of six recipes samples were $4.55 \pm 0.01 ; 3.31 \pm 0.10 ; 4.30 \pm 0.06 ; 3.41 \pm 0.04 ; 4.0 \pm 0.11$ and $3.30 \pm 0.03$, respectively (Table 2). The initial level of Salmonella enteritidis in all recipes was around $6 \times 10^{5} \mathrm{cfu} / \mathrm{g}$. Salmonella enteritidis was able to grow in all mayonnaise recipes during storage at $5^{\circ} \mathrm{C}$ regardless the initial $\mathrm{pH}$ in the samples. Comparing Tables $5 \& 6$ it could be seen that inactivation of salmonella enteritidis at $22^{\circ} \mathrm{C}$ was more rapid than at $5^{\circ} \mathrm{C}$. The time for reduction of Salmonella enteritidis to the undetectable level at $5^{\circ} \mathrm{C}$ was after 192 hours, while at $22^{\circ} \mathrm{C}$ no microorganisms were detected after $48-72$ hours in all the recipes except recipe 1 which had no viable cells after 120 hours. The presence value increased whereas the amount of citric acid and storage temperature increased. Twenty five $\mathrm{ml}$ or more citric acid at $22^{\circ} \mathrm{C}$ were the boundary conditions (maximum or minimum requirements) for the absence of Salmonella enteritidis in citric acid home made mayonnaise after 72 hours storage. This confirmed that storage of mayonnaise at a lower storage temperature protects the Salmonella enteritidis to some extent against antimicrobial effects of organic acid used. Nearly similar findings were recorded by Xiong et al. (2000) and Ordonez et al. (2009). Our results disagree with Erickson and Jenkins (1991) and Saeed and Koons (1993) who reported that Salmonella enteritidis was unable to grow in home made mayonnaise at $22^{\circ} \mathrm{C}$, where as Davis and Wray (1996) and Leuschner and Boughtflower (2001) reported that Salmonella enteritidis was inactivated in mayonnaise adjusted to $\mathrm{pH} 4$ and stored at $4^{\circ} \mathrm{C}$. This difference may be attributed to the different mayonnaise formulations used in the studies, the interaction of $\mathrm{pH}$, temperature, antimicrobial ingredients, the physical and chemical properties of mayonnaise recipes used, the physical positioning of ingredients and the character of microorganisms throughout the mayonnaise recipes (Radford, 1994 and Yang et al., 2001). The shelf life of mayonnaise recipes samples stored at $22^{\circ} \mathrm{C}$ was much shorter than at $5^{\circ} \mathrm{C}$. All mayonnaise samples stored at $22^{\circ} \mathrm{C}$ were spoiled by molds after 7 days, while no visible molds were observed after 9 days of storage at $5^{\circ} \mathrm{C}$. Acidic $\mathrm{pH}$ in mayonnaise prevents the growth of most microorganisms commonly associated with food spoilage. However, spoilage of these products does occur as a result of the growth of lactobacilli, bacilli, and yeasts (Xiong et al., 2002 and Fialova et al., 2008). It was found that in recipe 1, addition of $20 \mathrm{ml}$ citric acid, did not affect Salmonella enteritidis up to $120 \mathrm{~h}$ at $22^{\circ} \mathrm{C}$, while in other recipes Salmonella enteritidis was inactivated by addition of at least $25 \mathrm{ml}$ citric acid at $22^{\circ} \mathrm{C}$ within 72 hours. This suggests that 
mayonnaise recipes using less than $25 \mathrm{ml}$ citric acid solution considered unsafe unless pasteurized eggs are used. Therefore, raw eggs would be a very high risk in food poisoning. If safe mayonnaise recipes could be eliminated, outbreaks of food poisoning attributed to home made mayonnaise may be reduced significantly or even eliminated (Clay and Board 1991; Humphrey, 1994; Knabel, 1995; Murphy, 1999; Smittle, 2000; Chouard, 2005; Guilmineau and Kulozik, 2007 and Cherington et al., 2008). To maintain Salmonella enterica serovar enteritidis free mayonnaise prepared with pure lemon juice (citric acid concentration $>5 \%(\mathrm{w} / \mathrm{v})$. So, it is recommended that $\mathrm{pH}$ should be in the range of $3.3-$ 4.3 using $25-40 \mathrm{ml}$ pure lemon juice, and the product should be held at $22^{\circ} \mathrm{C}$ for at least $72 \mathrm{~h}$ before consumption or refrigeration. This recommendation is made with regard to the advice of the Chief Medical Officer that eating raw eggs should be avoided for vulnerable people such as elderly, sick, babies and pregnant women, while pasteurized egg should be used (Department of Health, 1998). Pepper, sugar, and mustard have no effect on Salmonella entritidis. Nearly similar findings were reported by Membere et al. (1997); Baron et al. (2000); Guerzoni et al. (2002) and Leuschner and Juliette (2002). In contrast, Xiong et al. (1999 and 2002) recorded that high salt content affect the viability of Salmonella enteritidis in mayonnaise.

The results of the present study concluded that, to produce safe mayonnaise free from Salmonella enterica serovar enteritidis, lemon juice (concentration $\geq 5 \% \mathrm{w} / \mathrm{v}$ ), at least $25 \mathrm{ml}$ citric acid should be used as an acidulant to achieve $\mathrm{pH}$ between $3.3-4.3$ and stored in a warm place at $22^{\circ} \mathrm{C}$ for 72 hours before being consumed or refrigerated.

\section{ACKNOWLEDGMENT}

Special thanks to Nile S.P.F. project, Agriculture research center (Kom- Oshim- Fayoum governorate) for providing S.P.F. eggs and to the culture collection of Health ministry central laboratories for providing Salmonella enterica serovar enteritidis strain used in this study.

\section{REFERENCES}

Abu -Ghoush, M.; Samhouri, M.; Al-Holy, M. and Herald, T. (2008): Formulation and fuzzy modeling of emulsion stability and viscosity of a gum-protein emulsifier in a model mayonnaise system. J. Food Engin. 84 (2) 348-357. 
Abu-Jdayil, B. (2003): Modelling the time dependent rheological behaviour of semisolid foodstuffs. J. Food Engin. 57 (1) 97102.

Abu-Salem F.M. and Abou-Arab A.A. (2008): Chemical, microbiological and sensory evaluation of mayonnaise prepared from ostrich eggs. Grasas y aceites, 59 (4) 352-360.

Anon, T.J. (1989): House of Commons session 1988-1989. Agricultural committee. First report- Salmonella in eggs, vol 2. minutes of evidence and appendices. London, Her Majesty's Stationary Office.

Anon, T.J. (2000): Trends in selected gastrointestinal infections: Communicable Dis. Rep. 10 (1) 2- 9.

Baron, F.; Gautier, M. and Brule, G. (2000): Factors involved in the inhibition of growth of Salmonella enteritidis in mayonnaise. J. Food Prot. 63 (11) 1318-1323.

Batista, A.P.; Raymundo, A.; Sousa, I. and Empis, J. (2006): Rheological characterization of coloured oil-in-water food emulsions with lutein and phycocyanin added to the oil and aqueous phases during mayonnaise. Manufacture. Hydrocolloids, 20, 44-52.

Brabant, L.E. (1992): The dressings: new sales opportunities in Japan. Ag. Exporter J. 4 (1) 12-13.

Cherington, C.; Hinton, M.; Mead, G. and Chopra, I. (2008): Organic acids: chemistry, antibacterial activity and practical application. Adv. Microbiol Physiol. 32 (1) 87-108.

Chouard, G. (2005): Hygienic quality of low-fat mayonnaise. Food Technology, 29, 98-100.

Clay, C.E. and Board, R.G. (1991): Growth of Salmonella enteritidis in artificially contaminated hens'egg. Epidemiol. Inect. J. (2) 271-281.

Davis, C. and Reeves, R. (2002): High value opportunities and risks from the chicken eggs. A Report for the Rural Industries Research and Development Corporation.

Davis, R. and Wray, C. (1996): Persistance of Salmonella enteritidis in poultry units and poultry food. Br. Poultry Sci. 37 (3) 589-596.

Department of Health (1998): Expert advice repeated on Salmonella and raw eggs. Available from http/l www. Coi.gov.uk/coi/deptGDH/coi0316c.ok (accessed October 5, 1998). 
Depree, J. and Savage, G. (2001): Physical and flavor stability of mayonnaise. Trends Food Sci. Tech. 12, 157-163.

Donaghy, J. and Madden, R. (1993): Detection of Salmonella in animal protein by Rappaport-Vassiliadis broth using indirect impediometry. Int. J. Food Microbial., 17 (2) 281-288.

Erickson, J. and Jenkins, P. (1991): Comparative Salmonella species and Listeria monocytogenes inactivation rates in four commercial mayonnaise products. J. Food Prot. 54 (7) 913916.

Fialova, J.; Chumchalova, H. and Mikova, K. (2008): Effect of food preservatives on the growth of spoilage lactobacilli isolated from mayonnaise-based sauces. Food Control. 19 (7) 706-713.

Grodzka, K.; Maciejec, A. and Krygier, K. (2005): Attempts to apply microcrystalline cellulose as a fat replacer in low fat mayonnaise emulsions. Food Control. 16 (1) 52-61.

Guerzoni, M.E.; Vannini, L.; Lanciotti, R. and Gardini, F. (2002): Optimisation of the formulation and of the technological process of egg-based products for the prevention of Salmonella enteritidis survival and growth. Int. J. Food Microbiol. 73 (3) 367-374.

Guilmineau, F. and Kulozik, U. (2007): Influence of a thermal treatment on the functionality of hens egg yolk in mayonnaise. Journal of Food Engineering, 78, 648-654.

Hoffmann, G. (1989): The chemistry and technology of edible oils and fats and their high fat products. Academic press. $1^{\text {st }}$ Ed. Inc., Great Britain. Eddmundsbury, p. 221-240.

Holtby, I.; Tebbutt, M.; Anwar, M.; Aislabie, J.; Bell, B.; Flowers, Hedgley, W. and Kelly, P. (2006): Two separate outbreaks of Salmonella enteritidis phage type 14B food poisoning linked to the consumption of the same type of frozen food. Public Health. 120 (9) 817-823.

Humphrey, T.J. (1994): Contamination of egg shell and contents with Salmonella enteritidis. Int. J. Food Microbiol. 21 (1) 31-40.

Irwin, D.; Rao, M.; Barham, D.; Pencheon, C.; Lofts, P.; Jones, H.; Omanony, M. and Ward, R. (2008): An outbreak of infection associated with Salmonella enteritidis phage type 4 associated with the use of raw shell eggs. CDR review. 3 (13) 179-183.

Jay, J.M. (1992): Modern food microbiology, $4^{\text {th }}$ Ed. Chapman and hall, New York, pp 465-469. 
Karas, $R$. and Skvaraa, M. (2002): Sensory quality of standard and light mayonnaise during storage. Food Tech. Biotech. 40 (2) 119127.

Kim, M.; Shim, Y.; Park, K.; Young, I.; Sejong, O. and Young, J. (2009): Optimization of the enzymatic modification of egg yolk by phospholipase $\mathrm{A}_{2}$ to improve its functionality for mayonnaise production. Food Science and Technology 4 (1) 250-255.

Kishk, Y.M. (1997): Role of some vegetable oils in mayonnaise characteristics, M.VSc. Thesis. Faculty of Agric., Ain Shams University, Egypt.

Knabel, S.J. (1995): Food borne illness: Role of home food handling practices. Food technol. 49 (4) 119-131.

Leuschner, R. and Boughtflower, P. (2001): Standardized laboratory scale mayonnaise containing low level of Salmonella enteritidis. J. Food Prot. 64 (6) 623-629.

Leuschner, R. and Juliette, Z. (2002): Effects of spices on growth and survival of Escherichia coli 0157 and Salmonella enterica serovar enteritidis in broth model systems and mayonnaise. Food Control. 13 (6-7) 399-404.

Liu, H.; Xu, M. and Guo, D. (2007): Rheological, texture and sensory properties of low fat mayonnaise with different fat mimetics. J. Food Sci. Technol. 40 (5) 946-954.

Marshall, R.T. (1992): Standard methods for the examination of dairy products. Washington, DC: American Public Health Association.

McClements, D.J. (1999): Food emulsions. Principles, practice and techniques. Boca Raton, FL, CRC academic press, London, 200-239.

Membere, J.; Majchrazak, M. and Jolly, I. (1997): Effects of temperature, $\mathrm{pH}$ and citric acid on the inactivation of Salmonella typhimurium in reduced calorie mayonnaise. J. Food Protect. 60 (10) 1497-1501.

Meyer, S.; Grant, M.; Luedecke, L. and Leung, H. (1995): Effects of pH and water activity on microbiological stability of salad dressing. J. Food Prot. 58 (7): 477-479.

Morgan, O.; Milne, L.; Kumar, S.; Murray, D.; Man, W.; Georgiou, M.; Verlander, Q.; De Pinna, E. and McEvoy, M. (2007): Outbreak of Salmonella enteritidis phage type 13a: case control investigation in Hertsmere, United Kingdom. Euro Surveill. 12 (7) $9-10$. 
Murchie, L.; Bin, X.; Robert, H.; Madden, A.; Paul, W. and Louise, K. (2008): Qualitative exposure assessment for Salmonella spp. in shell eggs produced on the island of Ireland. Int. J. Food Microbiol. 125 (3) 308-319.

Murphy, P. (1999): Low fat mayonnaise developments. Food Technology International, 22 (1) 124-130.

Ordonez, A.; Fernandez, A.; Bernardo, A. and Mercedes, L. (2009): Comparison of acids on the induction of acid tolerance response in Salmonella typhimurium, consequences for food safety. Meat Sci. 81 (1) 65-70.

Pearales, I. and Audicana, A. (1989): The role of hens egg in outbreaks of Salmonellosis in North Spain. International Journal of Food Microbiology. 8 (1) 175-180.

Pearales, I. and Garcia, M. (1990): The influence of $\mathrm{pH}$ and temperature on the behavior of Salmonella enteritidis phage type 4 in home- made mayonnaise. Lett. App. Microbial., 10, 19-22.

Peressini, D.; Sensidoni, A. and Cindio, D. (1998): Rheological characterization of traditional and light mayonnaises. J. Food Engin. 35 (3) 409-417.

Radford, S.A. (1994): Factors affecting the fate of Salmonella enteritidis pt 4 in mayonnaise. Ph. D. Thesis. Bath University, UK.

Radford, S.A. and Board, G. (1993): Review: Fate of pathogens in home-made mayonnaise and related products. Food Microbiology, 10, 269-278.

Roberts, D.; Hooper, W. and Greenwood, M. (1995): Practical food microbiology. $2^{\text {nd }}$ Ed. London: Public Health Laboratory Service.

Rodrigue, D.C.; Tauxe, R.V. and Rowe, B. (2008): International increase in Salmonella enteritidis. A new pandemic. Epidemiol. Infect. 105, (1) 21-27.

Rujirat, S.; Wong, C. and Manop, S. (2007): Carotenoids as colorants in reduced-fat mayonnaise containing spent brewer's yeast $\beta$ glucan as a fat replacer. Food Hydrocolloids. 21 (4) 565-574.

Saeed, A. and Koons, C. (1993): Growth and heat resistance of Salmonella enteritidis in refrigerated and abuse egg products. J. Food Prot. 56 (5) 927-933.

Smittle, R.B. (2000): Microbiological safety of mayonnaise, salad dressings and sauces produced in the United States: a review. J. Food Prot. 63 (8) 1144-1153. 
Stadelman, W.J. (1999): The incredibly functional egg and the associated health risk. Poultry Sci. 78 (5) 807-811.

Stefanow, L. (1998): Changes in mayonnaise quality. Lebensmittel Industire. 36 (2) 207-208.

Stern, P.; Valenteno, H. and Pokorony, J. (2001): Rheological properties and sensory texture of mayonnaise. European Journal of Lipid Science and Technology. 103 (1) 23-28.

Whiting, R.C. and Buchanan, R.L. (1997): Development of a quantitative risk assessment model for Salmonella enteritidis in pasteurized liquid eggs. International Journal of Food Microbiology, 36, 11-125.

Xiong, R.; Xie, G. and Edmondson, A.S. (1999): The fate of Salmonella enteritidis $\mathrm{pt} 4$ in home-made mayonnaise prepared with citric acid. Lett. Appl. Microbial., 28, 36-40.

Xiong, R.; Xie, G. and Edmondson, A.S. (2000): Modelling the $\mathrm{pH}$ of mayonnaise by the ratio of egg to vinegar. Food Control. 11 (1) 49-56.

Xiong, R.; Xie, G.; Edmondson, A.S. and Meullenet, J.F. (2002): Neural network modeling of the fate of Salmonella enterica serovar entritidis PT4 in home-made mayonnaise. Food Control. 13 (2) 525-533.

Yang, S.; Chui, Y. and Cheng, C. (2001): Influence of holding temperature on the growth and survival of Salmonella species and Staphyloccous aureus and the production of Staphylococcal enterotoxin in egg products. Int. J. Food Microbiol. 63 (1) 99-107. 